\title{
Solid Waste Management in Jogja Hospital
}

\author{
Muchsin Maulana ${ }^{1}$, Hari Kusnanto ${ }^{2}$, Agus Suwarni ${ }^{3}$ \\ ${ }^{1}$ Department of Public Health Science, Ahmad Dahlan University, Indonesia \\ ${ }^{2}$ Field Epidemiology Training Program, Gadjah Mada University, Indonesia \\ ${ }^{3}$ Health Polytechnic, Health Ministries, Indonesia
}

\section{Article Info}

Article history:

Received Jun 11, 2016

Revised Aug 20, 2016

Accepted Aug 26, 2016

\section{Keyword:}

Hospital

Management

Solid waste

Treatment

\begin{abstract}
There are some groups who may get the risks of hospital waste disposal. The first group is the patients who come to hospital to get cure and care. It is the most vulnerable group. The second is hospital's employees who have direct contact with the patients as main illness's agents on doing their daily duties. The third group is the visitor or those who accompany the patients; their risk is big as well. The last group is the society, people who live near the hospital, even when the waste siposal is done inappropriately. It causes the decrease of environmental quality which leads to the decline of health quality in the area. Hence, hospital has a responsibility to manage the disposal process of waste correctly and appropriately by conducting sanitation programs in hospital. Jogja Hospital is a Government-owned Hospital run by the Government of city of Yogyakarta. In its daily activities, the hospital produces waste which, if not properly discharged or burned, may cause adverse effect on workers as well as the surrounding area. Jogja hospital has Incinerator, thus simplifying the management such waste. The waste management including the rules, procedures and policymaking need to be explored to investigate the process of waste management of Jogja hospital.
\end{abstract}

Copyright $@ 2016$ Institute of Advanced Engineering and Science. All rights reserved.

Corresponding Author:

Agus Suwarni, Health Polytechnic, Health Ministries, Indonesia.

Email: mm311086@gmail.com

\section{INTRODUCTION}

Hospital as a means of health, a place for patients or health people, may be the vulnerable place to spread disease, and to contaminate the environment and health problems [1]. Environmental Health Management is recently considered not as a consumtive part, but a set of stages and strategies of hospital mamagement to develop its capacity in managing hospital environment to give direct or indirect benefits to the service quality in a whole. Environmental Health Management has complicated problems in. One of them is the waste problem which closely relates to Government Laws. Hospital as one of the biggest wasteproducers is potentially cause environmental pollution to the surrounding, and will likely give loss to the society and the hospital itself [2].

There are some groups who may get the risks of hospital waste disposal. The first group is the patients who come to hospital to get cure and care. It is the most vulnerable group. The second is hospital's employees who have direct contact with the patients as main illness's agents on doing their daily duties. The third group is the visitor or those who accompany the patients; their risk is big as well. The last group is the society, people who live near the hospital, even when the waste siposal is done inappropriately. It causes the decrease of environmental quality which leads to the decline of health quality in the area. Hence, hospital has a responsibility to manage the disposal process of waste correctly and appropriately by conducting sanitation programs in hospital [3]. 


\section{RESEARCH METHOD}

The research is a qualitative descriptive one with the primary objective to figure out real condition and description of it objectively [4]. It is a case study as a more suitable strategy for the questions of how and why when the researcher has a little chance to control the observed events, and when the focus of the research is a contemporary phenomena in real life [5].

\section{RESULTS AND ANALYSIS}

\subsection{Process of solid waste management}

\subsubsection{Treatment process of medical solid waste}

Figure 1 tells the treatment process of medical solid waste by PPL at Jogja Hospital.

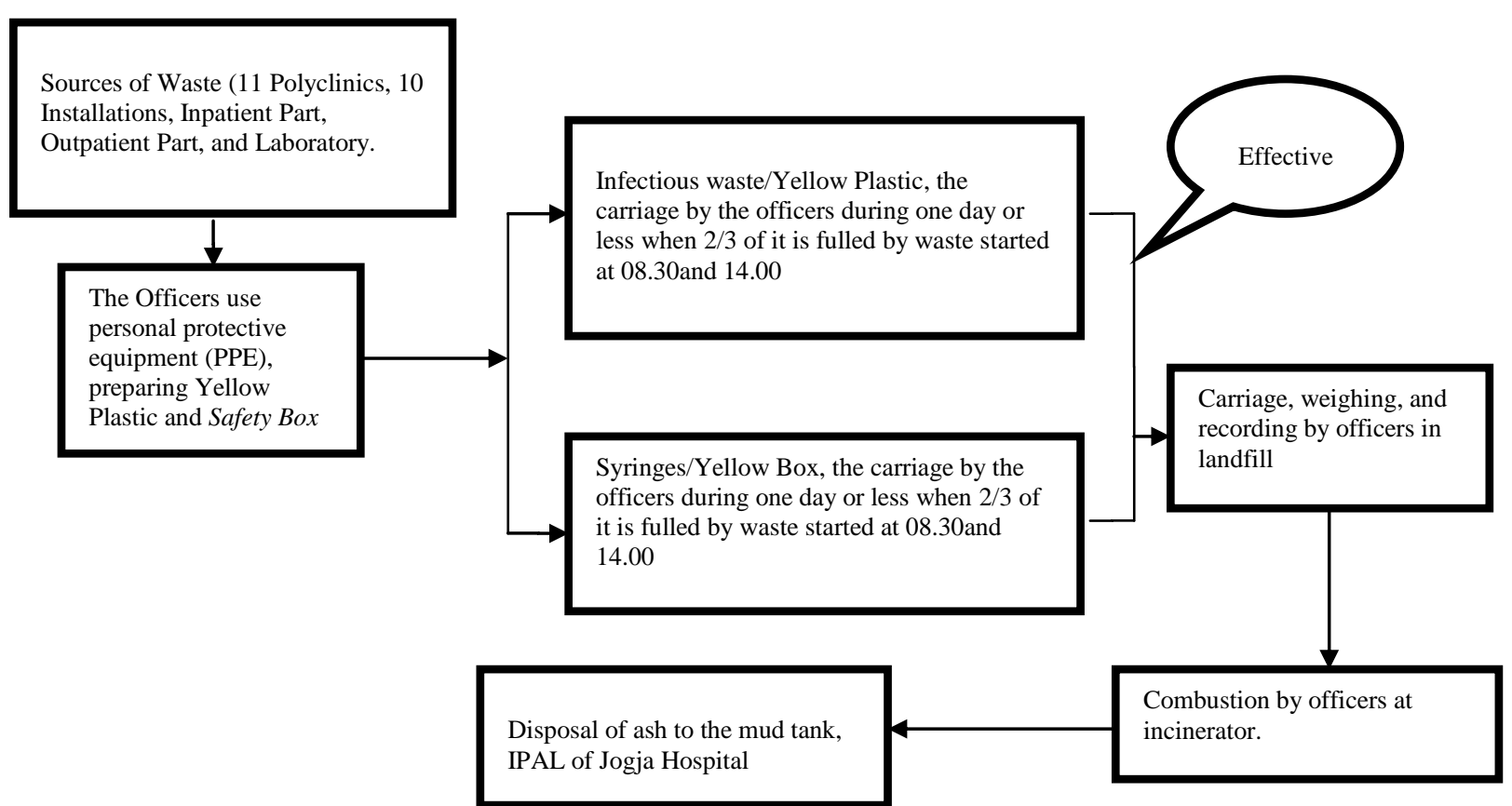

Figure 1. The treatment process of medical solid waste done by PPL at Jogja hospital

Description of solid medical waste treatment process Hospital Jogja is almost the same with [6], that the separation and similar waste reduction and waste volume reduction is an important security requirement for officers garbage dumping. Means adequate shelter infectious waste must either location, and hygiene. Research [7] in five hospital explained that the Hospital and Practice nurses were registered in these facilities are under constant surveillance and punished with the procurement of fines, if any disposable plastic or sharp objects were found in the yellow bag, forced check back their waste because it can result in injury to the health workers. Research [8], ideally the individual waste containers must be brought to the mass carts, staff have appropriate work clothes that include disposable aprons and gloves, the gloves should be burned and disposed of upon completion of the task.

This observation is very positive compared to studies conducted in Delhi, India which reported that the low quality of the incinerator has been installed in many hospital cause more harm [9]. Because they operate at temperatures below $300^{\circ} \mathrm{C}$ and discharge of toxic emissions into the environment and cause harm indispensable for public health, and does not meet the standards set by the rules of Bio-Medical Waste, which states that the efficiency of combustion must be at least $99 \%$ with zero emissions standards dioxins, furans, heavy metal vapors, harmful particles, by the Rules of Bio-Medical [9]. Better sewage treatment causes a decrease in heavy volume, risk of infection and waste organic compounds [10].

Research [11] indicate that the main problem Hospital in Khuzestan province in the processing of solid waste is due to improper storage in packing and transportation of solid waste. Research [12] explained that the untreated medical waste can cause environmental pollution that causes aesthetic problems and may be the talk of the media. Research [13] our study found that waste management handling practices were better in the studied hospitals in Thailand than in Mongolia and Pakistan. The study findings showed that in 
the hospitals studied in Bangkok, conscious efforts had been made to maintain a high standard in hygiene, safety, and waste management in addition to offering state of the art medical facilities to attract customers, due to the recent increase in medical tourism from abroad.

Research [6] explained that the sewage collection lines arranged to be transported to the incinerator to be destroyed, so it does not coincide or do not intersect with the schedule of deliveries of food and clean linen on the same path. The treatment process of medical solid waste at Jogja Hospital which is done by PPL in a day or less when $2 / 3$ of it is fulled by waste carries out the effective stages, specific phases and short term process.

\subsubsection{Treatment process of non-medical solid waste}

Figure 2 tells the treatment process of non-medical solid waste by PPL at Jogja Hospital.

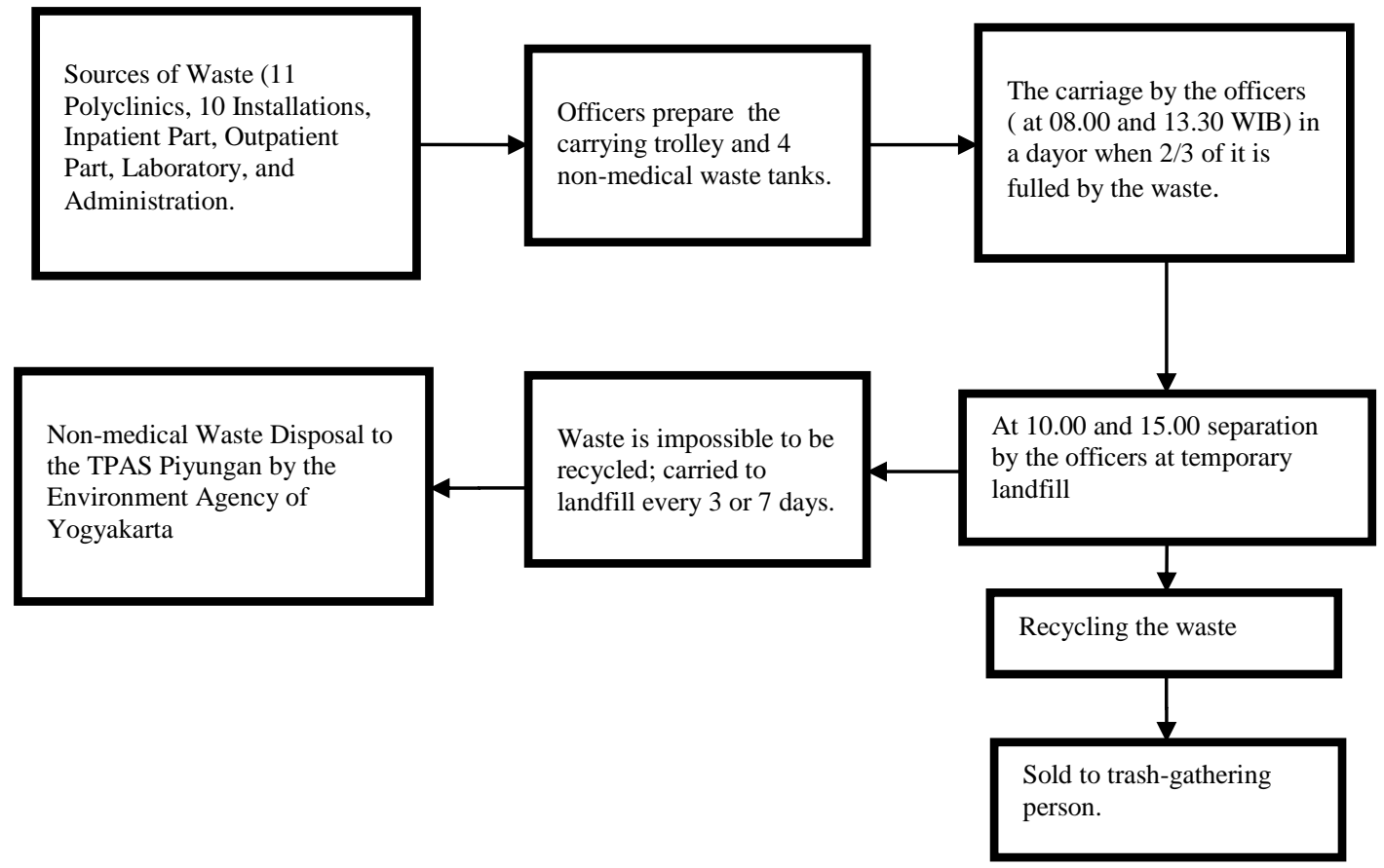

Figure 2. The treatment process of non-medical solid waste done by PPL at Jogja hospital

Hospitals Places where waste is stored before being taken to the final disposal site is termed as a temporary storage of waste. This area should be cleaned and secured in such a way and can only be accessed by authorized persons [10]. [8] explains, when it was more than two-thirds full, primary waste containers sealed and taken permanently discarded. In most hospitals, bulk garbage carts used to facilitate the collection of waste from the clinical area, and for temporary storage of waste until the carriage by the contractor for final disposal.

Research [6] states that the disposal of medical waste into the bag which is supposed to lead to a very dangerous kitchen waste, if the waste contains materials that infectious disease transmission, there will be undesirable. Research [14] on two major hospital in Dhaka City (DMCH and BMCH) generally found that the dumping of waste into the basket without separated. Research [15] in the process of integration: collection of materials for recycling and composting must be linked with the available markets for these materials; waste collection and handling must also be integrated with anaerobic treatment, processing and disposal activities; the biological treatment facility, collection, recycling and composting programs must be brought in close co-operation with the management authorities, the public and private investors.

This behavior pose a serious health risk to workers handling waste, to scavengers at the landfill and to society in general. The consequences of this practice that pollute surface water and groundwater resources around the landfill.The treatment process of non-medical solid waste done by PPL at Jogja Hospital applies different stages as some temporary waste basket at the hospital have already categorized it into paper, plastic or glass waste. There is only low possibility that the waste will accumulate, and it takes less time of carrying process as PPL need not to recheck the recycle or nonrecycle waste. 


\subsection{Recycling process}

Recycling process that is in the Hospital Jogja using a planned inter-Waste Management Officer, but has not been accommodated by the Installation Section of Environmental Health. Because the results from the sale of recycled waste collected by the WMO to be money coming in for these Officers. Recycling process that takes place gives difficulties for researchers, due to unavailability of data or reports are clear about the details of waste into recycling options at the Hospital Yogyakarta. Description of recycling Hospital Jogja is almost the same with research [16], that the waste collection and transportation workers in the Hospital separating recyclable waste for sale. In the same way, all disposable plastic items separated by scavengers, where garbage is stored both in the hospital courtyard, or outside in the community hospital for further transportation and disposal along with municipal solid waste.

World Health Organization [3], explains that the medical equipment and other equipment used in health care facilities can be reused as long as it is designed according to these objectives and can survive the sterilization process. Goods that can be reused can include sharp tools such as skapel and needles, syringes, bottles and glass containers can be sterilized. Research [17] the hospital should also undertake a detailed risk assessment of the waste. A policy needs to be formulated based on 'reduce, reuse, recover and dispose'. Manufacturers of medical supplies should be encouraged to supply products that have a smaller impact on the environment. It is very important to segregate the waste before treatment and disposal because this helps to identify hazardous and potentially infectious waste and thereby reduces overall handling cost.

The basic approach to the management of medical waste is to reduce the amount of garbage at source as far as possible [18]. Hospital waste should be recycled whenever feasible, with due respect to the environment, to reduce the quantity of hazardous substances into the nature. Waste plastic materials and empty bottles taken by the staff of sanitation to be sold to waste collectors [19]. The percentage of materials recycled by the scavengers have a direct contribution to the saving of waste management and officials responsible for the cost of the hospital waste disposal [20]. Recycling process that is applied at the Jogja Hospital is not yet efficient, because the proceeds from the sale of non-medical wastes Hospital should be money for the Hospital Yogyakarta.

\subsection{Amount of waste in Combustion}

Here is the amount of waste combusted on incinerator based on the data ofEnvironmental Health istallation at Jogja Hospital [Table 1].

Table 1. The amount of Medical and Non-medical Solid Waste at Jogja Hospital

\begin{tabular}{|c|c|c|}
\hline & Medical & Non-medical \\
\hline Amount & $500 \mathrm{M}^{3}$ & $64 \mathrm{M}^{3}$ \\
\hline Source & $\begin{array}{l}\text { Solid waste produced by all medical } \\
\text { activities at Jogja Hospital }\end{array}$ & $\begin{array}{l}\text { Solid waste produced by all non-medical } \\
\text { activities at Jogja Hospital }\end{array}$ \\
\hline Treatment Process & Combusted on hospital's incinerator & $\begin{array}{l}\text { Separation of recycle and non-recycle } \\
\text { waste (sold to trash-gathering person) }\end{array}$ \\
\hline Disposal & $\begin{array}{l}\text { Disposal of ash to the mud tank, IPAL of } \\
\text { Jogja Hospital }\end{array}$ & $\begin{array}{l}\text { The disposal is incooperation with DLH } \\
\text { Yogyakarta }\end{array}$ \\
\hline
\end{tabular}

*Source: Environmental Health Istallation at Jogja Hospital

Well-designed incinerator has to burn waste by leaving the rest in the form of ash and must be fitted with a scrubber to trap toxic air pollutants that are released [21]. [22] states that if waste were disposed of without pretreatment (still stored chemicals, disinfection, steam autoclaves) and imperfectly burned, then it still may contain potentially harmful microorganisms. [22] states that when children and scavengers were exposed to the waste pile, there is a strong possibility that they will get an infection or injury, and if the combustion temperature is open below $800^{\circ} \mathrm{C}$, this method can be a source of toxic pollutants in smoke or in the form of particles.

M. Ali and C. Kuroiwa suggests that private organizations involved in waste collection developing health over time, the need and demand. Some hospitals in Thailand have been delegated the management of pain house waste to private organizations [23]. Workers collect garbage at a certain point then separated and finally transported to the extermination Hospital partners. 


\section{CONCLUSION}

The treatment process of solid waste at Jogja Hospital carries out the effective stages, specific phases and short term process. It prevents waste accumulation as well as avoiding illness. The treatment process of non-medical solid waste at Jogja Hospital applies different stages as some temporary waste basket at the hospital have already categorized it into paper, plastic or glass waste. Recycling process at Jogja Hospital has not been considered effective as non-medical waste selling should give additional income to the hospital.

\section{REFERENCES}

[1] Indonesian Ministry of Health, Nomor: 1204/MENKES/SK/X/2004, "Terms of Environmental Health Hospital," Jakarta, Dirjen PPM\&PL Depkes RI, 2004.

[2] Adisasmito, "Environmental Audit Hospitals," Jakarta, Raja Grapindo Persada, 2008.

[3] WHO, "Management of Wastes From Health-Care Activities," Cetakan Pertama, Jakarta, EGC, 2005.

[4] S. Notoatmodjo, "Health Research Methodology," Cetakan Ketiga, Jakarta, PT Rineka Cipta, 2005.

[5] R. K. Yin, "Case Study Research: Design and Metods," Cetakan Kesembilan, Jakarta, Devisi Perguruan Tinggi Rajawali Pers, 2009.

[6] B. Alamsyah, "Waste Management in Hospitals Pupuk Kaltim Bontang to Get Environmental Quality Standards," Tesis, UNDIP, Semarang, 2007.

[7] L. C. S. Rao, W. C. R. Ranyal, L. C. S. Bhatia, L. C. V. Sharma, L, "Biomedical Waste Management: An Infrastructural Survey of Hospitals," Contemporary Issue, MJAFI, vol. 60, pp. 379-382, 2004.

[8] J. I. Blenkharn, "Potential compromise of hospital hygiene by clinical waste carts," Journal of Hospital Infection, vol. 63, pp. 423e427, 2006.

[9] G. V. Patil and K. Pokhrel, "Biomedical Solid Waste Management in an Indian Hospital: a Case Study," Journal of Waste Management, vol. 25, pp. 592-599, 2004.

[10] M. Askarian, M. Vakili, G. Kabir, "Result of Hospital Waste Survey in Private Hospitals in Fars Province, Iran," Journal of Waste Management, vol. 24, pp. 347-352, 2003.

[11] M. Karamouz, B. Zahraie, R. Kerachian, N. Jaafarzadeh, N. Mahjouri, "Developing a master plan for hospital solid waste management: A case study," Elsevier, 2006.

[12] B. Coronel, P. Duroselley, H. Behry, J. F. Moskovtchenko, J. Freneyy, "In situ decontamination of medical wastes using oxidative agents: a 16-month study in a polyvalent intensive care unit," Journal of Hospital Infection, vol. 50, pp. $207 \pm 212,2002$.

[13] M. Ali and K. Chushi, "Status and Challengges Hospital Solid Waste Management: Case Studies From Thailand, Pakistant, and Mongolia," The $3^{\text {rd }}$ expert meeting in solid waste management in Asia and Pasific islands. J Mater Cycles Waste Manag, vol. 11, pp. 251-257, 2009.

[14] M. M. Hasan, S. A. Ahmed, K. A. Rahman, T. K. Biswas, "Pattern of Medical Waste Management: Existing Scenario in Dhaka City, Bangladesh," BMC Public Health, vol. 8, pp. 36, 2008. doi: 10.1186/1471-2458-8-36.

[15] E. D. Anomanyo, "Integration of municipal Solid Waste Management In Accra (Ghana): Bioreactor Treatment Technology as an Integral Part of The Management Process," Thesis, Lund University, Sweden, 2004.

[16] K. V. Radha, K. Kalaivani, R. Lavanya, "A Case Study of Biomedical Waste Management in Hospitals," Global Journal of Health science, vol/issue: 1(1), 2009.

[17] S. Gupta and R. Boojh, "Biomedical Waste Management Practices at Balrampur Hospital, Lucknow, India," Waste Management Research, vol. 24, pp. 584, 2006.

[18] Dehghani M. H., K. Azam, F. Changani, E. D. Fard, "Assessment of Medical Waste Management in Educational Hospitals of Tehran University Medical Sciences. Iran,” Jounal of Environment. Health. Science. English, vol/issue: 5(2), pp. 131-136, 2008.

[19] S. Rasheed, S. Iqbal, L. A. Baig, K. Mufti, "Hospital Waste Management in theTeaching Hospitals of Karachi," JPMA, vol. 55, pp. 192, 2005.

[20] M. A. Rahman, M. A. Rahman, M. A. Patwary, "Health Care Waste Management Issues in Bangladesh," The Journal of Solid Waste Technology and Management, 2008.

[21] G. Ali, V. Nitivattananon, N. A. Molla, A. Hussain, "Waste Management: A Case of Thammasat Hospital, Thailand," World Academy of Science, Engineering and Technology, vol. 64, 2010.

[22] S. Phengxay, J. Okumura, M. Miyoshi, K. Sakisaka, C. Kuroiwa, "Health-care waste management in Lao PDR: a case study," Waste Management Research, vol. 23, pp. 571-581, 2005.

[23] M. Ali and C. Kuroiwa, "Status and Challenges of Hospital Solid Waste Management: Case Studies from Thailand, Pakistan, and Mongolia," J Mater Cycles Waste Management, vol. 11, pp. 251-257, 2009. 